\title{
The Praxis of Cultural Sustainability: \\ A Q'eqchi' Maya Case of Cultural Autonomy and Resistance against the Monsanto Law in Guatemala
}

\begin{abstract}
YiShan Lea ${ }^{1}$
This paper explores the cultural ideology of the Mayas in regards to cultural sustenance from multiple perspectives. Rural consciousness and agricultural related rituals are described and analyzed to illustrate the ideological continuity concerning the cultural sustenance of the contemporary rural Q'eqchi' people. The embedded cultural symbols and agricultural ritual are examined to shed light on indigenous identity and to account for the cultural agency as the foundation of the praxis of cultural sustenance. The Q'eqchi' Maya consciousness in relation to their praxis of cultural sustainability will be discussed in five dimensions: 1). Indigenous rural consciousness and historical resistance, 2). The subsistence based economy model of milpa system, 3). A landscape of signs and symbols of Maya cosmology, 4). The ritual model of Maya cosmogony and the agricultural rituals for sowing and healing, 5). The indigenous peasant organizing for resistance and defeating the Monsanto Law. [Article copies available for a fee from The Transformative Studies Institute. E-mail address: journal@transformativestudies.org http://www.transformativestudies.org (C2018 by The Transformative Studies Institute. All rights reserved.]
\end{abstract}

KEYWORDS: Praxis of Cultural Sustenance, Q'eqchi' Mayas, Maya Animism, The Monsanto Law, San Agustin Lanquin, Guatemala.

\section{INTRODUCTION}

Multiple disciplines have observed cultural conservation in Maya communities from the 1980s to 2010, and from 2010 to 2015. Sapper observed that "the [Q'eqchi'] were very concerned, at least in the

\footnotetext{
${ }^{1}$ YiShan Lea, Ed.D., is Associate professor at Central Washington University. Her research interests include Freirean pedagogy, peasant studies, Mayan studies, and cultural sustainability. Address correspondence to: YiShan Lea, Central Washington University, 400 E. University Way, Ellensburg, WA 98926; e-mail: leay@cwu.edu.
} 